\title{
The vita Miltiadis of Cornelius Nepos.
}

\section{By Stanley Casson.}

The singular inadequacy of Herodotus to describe the events of the Persian Wars in an intelligible narrative which would be at once free from the influence of tainted sources and comprehensible in itself, renders it most necessary to take into account any shreds of evidence derived from sources other than his.

Cornelius Nepos in his Lives of Distingnishetl Generals provides not a little of such independent evidence, which, whatever its origin, seems to be free from those preconceptions implicit in evidence gleaned by the

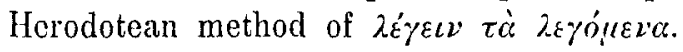

These lives of the Generals, long attributed to an otherwise unknown Aemilius Probus, were declared in 1569 by Dionysius Lambinus to be the work of Cornelius Nepos. A compromise between the rival views was ultimately reached in the decision arrived at that the actual existing text, as edited by Lambinus, was an epitome by Probus of the more lengthy originals by Nepos. Seeing that the text was used very extensively as a standard school book, we might go so far as to say that Probus abridged and simplified the longer versions with a view to using the work as a school book, rather than as a historical epitome.

But, whatever the truth about its authorship may be, this book of lives gives to the historian a unique collection of fragments of evidence bearing directly on the Persian Wars, and apparently derived, as will be shown later, from sources quite distinct from and in some ways superior to those of Herodotus ${ }^{1}$ ).

The life of Miltiades seems to contain the majority of such evidence and to be independent of all Herodotean inspiration. Both as a biography and as literature it is poor and its narrative shows little of the charm of Plutarch or of the style of Herodotus. It is not even accurate, for it confuses Miltiades the son of Kimon with his uncle Miltiades the son of

1) Macan, however, remarks that there is hardly a single item to be found in Cornelius which can be treated as authoritative'. Appendix I. 14. An unbiassed estimate of Cornelius alone can show how far this is correct. 
Kypselus by referring to the former the establishment of the colony in the Chersonese which was the work of the latter. But nevertheless it throws much light on the history of that tragic and desolate family, the Philaidae, and on the career of its most ill-fated member-the hero of Marathon.

The connection of the Philaidae with Athenian international relations, though slight, seems to have been important, and an account of the family seems to have an important bearing on the investigation of the sources used by Nepos. At the outset the Philaidae incurred the unpopularity of the ruling families of Athens: for Kimon the son of Stesagoras and the father of Miltiades was first exiled under Peisistratus and was subsequently assassinated by the Peisistratidae ${ }^{1}$ ).

During his exile, however, he kept up the traditions of his house by entering for and winning prizes in the chariot races at Olympia, and there is a story that by assigning the glory of one of his victories to Peisistratus he was permitted to return to Athens $v \pi \sigma_{0} \sigma \pi o v \delta \circ$. Miltiades the elder was the half-brother (by the same mother) of this Kimon, and he too incurred the hostility of Peisistratus, due, no doubt, to his excessive devotion to the older ideals of Attic aristocracy: for, as Herodotus says, he was

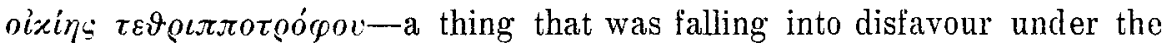
democratic rule of Peisistratus, who, in addition, could boast himself of no very ancient ancestry. Little wonder then that Miltiades 'chafed under the Peisistratid domination and wished to emigrate', and it was not long before Peisistratus facilitated his 'wish' by getting for him the "permission' of the Oracle to depart-a convenient form under which to exile disturbing elements in the State. He arrived at the Chersonese and we hear how after being seized by the men of Lampsakus he was released by order of Croesus, whose friendship he enjoyed, a friendship the more easily understood, when we remember the strong anti-Persian tendencies of his family. He died, however, shortly after, childless, and was succeeded by his nephew Stesagoras who in turn was assassinated after a brief space of time.

But the misfortunes of the family did not end with the luckless Stesagoras, for there is no more tragic career in Greek history than that of Miltiades the younger, and it is in the narrative of his life that the superiority of Nepos over Herodotus is demonstrated.

Miltiades the son of Kimon, Herodotus says, was sent by the Peisistratidae in 513 to the Chersonese. Apparently it was a case of exile, as with his father and uncle before him, though Herodotus tries to obscure this issue by explaining how oi (

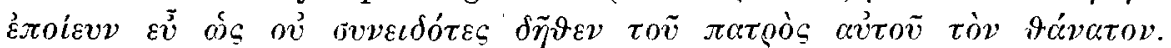
On his voyage to the Chersonese, says Cornelius Nepos, he stopped at

1) Herodotus VI. 103. 
Lemnos-and it is in this account of the Lemmian expedition that we first meet with the divergence between the narratives of Herodotus and Nepos, and the use by the latter of clearer documents and earlier historical traditions. On his arrival at Lemnos, Miltiades demanded its surrender and allegiance to Athens; the Lemnians replied that they would submit only when he sailed from his lome to Lemnos with a north wind. He, therefore, left Lemnos and proceeded to the Chersonese, where he effected a temporary organisation and settlement of his domains. Subsequently he returned to Lemnos and demanded the surrender of the island on the gound that the conditions previously made by the Lemnians had been fulfilled, as he had sailed on a northern wind from his home in the Chersonese. The Carians who then inhabited Lemnos, continues Nepos, submitted-resistere ansi non sunt atque ex insulce demigrarunt. After this it appears that Miltiades captured other islands for Athens-pari felicitate ceteras insulas quae Cyclades nominantur sub Athenionsium redegit potestatem, and we can see in this either a definite policy of forming an outer line of defence against P'ersia as he seems to have intended in the later Parian expedition, or else an interpretation of a raid in the light of the later fifth century when every expedition was for the purpose of subduing islands into the Athenian power').

However this may be, Herodotus barely alludes to the expedition at all, and what he does say seems confused. The anecdote, or rather the folk-tale, of Lemnos about Miltiades and the wind from the north he attributes to the Pelasgians (Pelasgians and Carians alike were types of Aborigines to Greek historians), and describes how it was uttered when, on the occasion of the Pelasgian atrocities in carly times ${ }^{2}$ ), Athens demanded the surrender of Lemnos. 'Very many years afterwards', he says, 'Miltiades the son of Kimon came from Elaeum in the Chersonese on the Etesian winds and ordered the Pelasgians to leave the island, reminding them of the oracle' (i. e., their answer to the Athenians when they visited them at the biddling of the oracle). Herodotus has obviously misplaced the whole story just as his account of the mission of Alexander after the battle of Salamis ought to have been inserted before the battle if the sequence of events is to be understood: the 'carrying out of apparently impossible conditions', though a universal type of folk-story, is nevertheless applicable much more to the occasion of the expedition of Miltiades to Lemnos than to the legendary mission of the Pelasgians to Athens.

After his return to the Chersonese, Miltiades was still dogged by the family misfortune. As far as we can gather from the very confused

1) Mitchell and Caspari's edition of Grote, page 159, note 2.

2) The earliness of the date is implied by Herodotus when he says that 'neither Athenians nor any other Greeks at that time owned slaves'. (vi. 137.) 
and uncertain text of Herodotus 1), he arrived in the first instance (after his first visit to Lemnos) at the Chersonese in 513 . In 510 he is expelled by an inroad of Scythians-and perhaps this is the occasion of his second visit of annexation to Lemnos. In 496, however, he returned to the Chersonese and remained there for three years till he was again expelled in 493. Thus between 510 and 496 he was in exile somewhere, but where he was and what he was doing neither Herodotus nor Nepos can tell us. The story of his life is taken up by the latter in $\$ 90$ or 491 , and we hear nothing of the trial which Herodotus mentions he had to undergo at the hands of his $\dot{\varepsilon} \chi^{\prime}$ ?ooi. What the trial was for and who precisely these $\dot{z} \chi^{i}$. were is not at all clear. It could not have been the Alcmaeonidae who were the $\dot{z}\left(\vartheta^{9} \circ i^{2} i^{2}\right.$, say Messrs. Mitchell and Caspari in their edition of Grote, for they were partisans of the ex-tyrant Hippias. They suggest that it

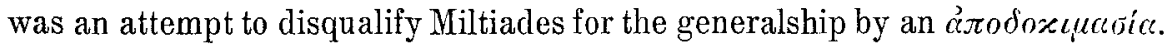
But he was accused immediately on his return from the Chersonese in 493 and he stood for the generalship in 490 : the Alcmaeonidae, moreover, could no doubt waive their scruples at times, and this accusation may have been the precedent for the subsequent accusation by Xanthippus after-the Parian débacle. They were further becoming unpopular, and the removal of Miltiades would be of inestimable service to their cause: perhaps they united, according to the best traditions of the Athenian three-party system, with the democracy of the rising Themistocles, to get the common enemy removed. But whatever was the cause of this attack, Miltiades appears to have gained increased popularity, and in the year

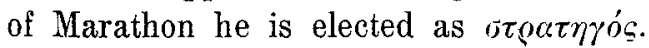

From this point Cornelius Nepos and Herodotus give parallel accounts of the events leading up to Marathon and the Parian expedition.

On the approach of the Persians after the collapse of the defences

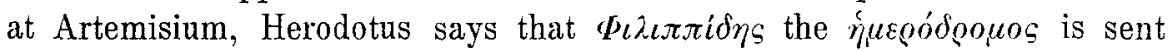
to Sparta "while the Athenians still remain in their city". Nepos states the bare fact, but calls the runner Phidippus, and emphasises the point that he was a runner eius generis qui hemerodromoe vocantur. There now took place, according to Nepos, the dispute among the generals as to what plan of action to adopt: the dispute is described and Miltiades' arguments given. Herodotus rather unaccountably attributes the whole affair to the time when the Athenians were ready for battle, a time when such a dispute would be both unlikely and undesirable: it was after the arrival of the Plataeans, he says, that Érivovto di $\chi \alpha$ ai $\gamma v \tilde{w} u \alpha u$.

In the speech of Miltiades reported by Herodotus he is made to say that victory at Marathon would be as great as the act of freedom of

1) Herodotus vi. $40 .-$ 2) p. 146 , note 1. 
Harmodius and Aristogeiton; perhaps we have here a further clue as to the enmity of the Peisistratidae, who were as antagonistic to the earlier members of the Philaid family as were the Alemaeonidae to the later: for the reference to the tyrannicides would hardly seem apposite unless their memory was cherished by Miltiades.

The arrival of the Plataeans raises the problem of the exact numbers of the Greek army. Nepos says that the total was 10,000 including the Plataeans-horum ardventu decem milia armatorum completa sunt. Pausanias and Plutarch give the same numbers, but Justin makes it 11,000, giving 10,000 Athenians 1000 Plataeans. The order of the narrative of Nepos makes the Plataeans arrive at A thens and after they had joined forces Athenienses copias ex urbe ciluxerunt, locoque idoneo castra fecerunt. Herodotus, with what seems like disregard for the more probable chronological order, times the arrival of the Plataeans after the Athenians had taken up their position-'Aq

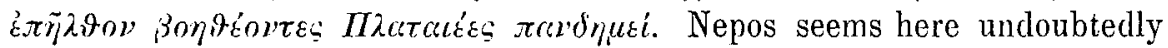
to follow the better tradition, howeyer preferable it may be from the melodramatic point of view to time their arrival at a critical moment.

His account is still further strengthened by topographical arguments, for there is no direct communication between Plataea and Marathon. The road from Plataea to Athens is straightforward enough, but the only way to reach Marathon without first going to Athens would be by going first to Thebes and thence to Eleon and Oropus and across the spurs of Mt. Parnes to Aphidna and so to the northern end of the plain of Marathon, and this would be a considerably longer march and a much more difficult road than if they went direct to Athens and then on to Marathon by the coast route. Of course Herodotus may have meant that the Plataeans went to Athens and, finding that Miltiades had already set out, followed him later: but he does not say that they went to Athens, and it seems highly probable that he thought that they came direct from Plataea to Marathon.

The most striking divergencies between the two accounts, however, appoar in the subsequent narrative of the actual fight. The Greeks, says

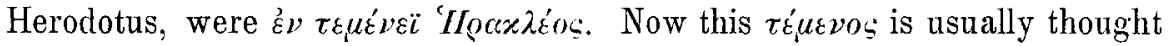
to be half-way up the mountain side in the valley of Avlona, where tradition and probability alike would place it. It was from this eminence, about a mile from the Persian camp according to traditional accounts, that the Greek forces descended at the double, gaining impetus as they

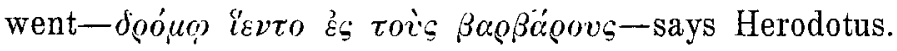

But Nepos gives an entirely different version. After their departure from Athens the Greeks go straight and camp loco idloneo. Then without the delay of several days which Herodotus states took place (probably in order that he could find time for his mis-timed debate of the generals) 
postero die sub montis radicihus acio regione instructa nona arte ${ }^{1}$ ) wi summa proelinu comiserunt.

In this sentence no less than three new pieces of evidence appear. The first is the immediate action of the Greeks without the delay postulated by the confused chronology of Herodotus? ${ }^{2}$. The second is that, whether their camp was on the level or on the hill, they began the battle not from the slopes as Herodotus implies, but from the foot of the mountains on the plain. The third is the assertion of the new strategy'- 'nova ars'- used by the Greeks. In regard to the latter point both Herodotus and Nepos seemed to have gathered from the sources they used that there was some striking new feature about the battle: Herodotus, however, is at a loss to say precisely what this nova ars was:

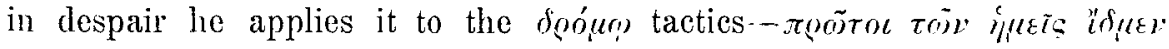

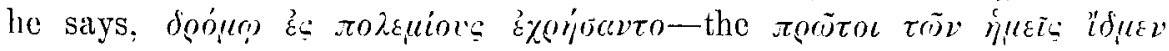
implying the 'novelty' of the manouvre.

But, on reflection, to advance at the double nuon one s enemies could hardly have been in innovation at the time of Marathon, and it seems foolish to give such prominence to so ordinary a matter. Incidentally, the difficulty critics have felt in understanding how a hoplite force conld traverse a mile at the double and have strength enough left at the end to fight seems lessened if we accept this statement of Nepos, according to which the Greek camp was not on the mountain side, but well down on the plain, for then the Greeks would have considerably less distance to cover $\left.^{3}\right)$.

On the face of it Herodotus seems to have missed the point and to have lost some valuable piece of evidence.

Nepos, however, seems to supply this lost evidence and to give quite a reasonable explanation of this nova ars: namque arbores, he says, multis locis erant rarae and so proelium commisermt hoe consitio ut et montium tegeventur altitudine et arborum tractu cquitatus hostium impedivetur ne multitudine clauderetur.

1) Stange's edition reads non apertissima for nova arte, which appears in the first printed text. Whichever reading has better authority, nova ars is a

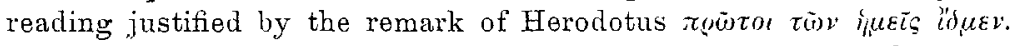

2) To account for the five or six days' delay by adducing as a reason the waiting of Miltiades for the division of the Persian forces, and the waiting of the Persian forces for a signal from Athens, explains merely how the time was spent, not why it was spent. The delay was not necessary for either side: the Alcmaeonid intriguing might equally well have taken place in the preceding week.

3) Herodotus, of course, says that the distance between the rival armies was eight stades (ch. 112), but this assumes that the Greeks were in the Heracleium, which is not assumed by Nepos. 
Now whichever historian may seem on the whole to be more reliable, it appears fairly obvious that Nepos gives at least a coherent account of the battle, implying that it was skilfully conducted and a triumph of tacties. All we learn from Herodotus is that it was a wild forlorn hope of men inspired with almost supernatural courage. On the face of it, Cornelius Nepos is preferable, and he at least would have no purpose to serve by elaborating the Herodotean version and improving it with touches of military realism. Herodotus, on the other hand, as will be subsequently discussed, drew from sources which were bitterly antagonistic to Miltiades and Philaid traditions, and which would go to no little trouble to deprive Miltiades even of the semblance of military ability. The whole account of Nepos, in fact, gives an absolutely different version of the battle. Four very important points are emphasised: points which completely alter the traditional conception of the battle. Firstly, there is the assertion that the plain of Marathon near the Greek camp was covered with trees scattered here and there fairly frequently; in the second place the mountain at the rear of the Greeks was of some strategic advantage; thirdly, this first fact-namely, the occurence of trees on the plain-was made use of to hinder the movements of the enemy's cavally: fourthly, the mere mention of cavalry goes far to dispose of many difficulties which had been brought about by their absence in the Herodotean version.

In regard to the first point, it is generally believed that the plain of Marathon has been from time immemorial not only treeless but actually a marsh in some places. Thus Grote, quoting Finlay, says, "the uninterrupted flatness of the plain is hardly relieved by a single tree' 1). Now however true this is to-day we need definite proof of the assertion that it was equally true in $490 \mathrm{~B}$. C. before we can dispute the very uncompromising statement of Nepos. And not only is the proof for such a dogmatic statement as Grote's not to be found, but there is every likelihood that in the $5^{\text {th }}$ century B. C. the opposite was the case; for it has been shown ${ }^{2}$ ) that Greece has suffered from a steady loss of vegetation: its surface is becoming every day less covered with trees, and evidence is now forthcoming of the greater prevalence of forest zones in earlier times-particularly in northern Greece. But as a matter of fact all that Cornelius Nepos says is that the plain was covered with 'trees at intervals', and this is a description that applies admirably to the typical Greek 'scrubland' or 'bush'.

1) IV p. 274

2) Zimmern, The Greek Commonuealth p. 41 . Even in the last thirty years the area of forest land is said to have been reduced by one half. Cf. Mrres, Greek Lands and Greek People. 
Now the statement about the strategical value of the mountain is curious and rather diffienlt to understand. Presumably the meaning of ut montium tegerentur altitudine is that the mountain prevented them from being enfiladed or cut off in the rear, for if they were drawn up sub montis radicibus it would be almost impossible to surprise them in the rear or flank. But the safety of this position would apparently only apply as long as they remained there, for as soon as they left the radices montium they would obviously be unguarded on both rear and flank.

But by far the most illuminating evidence is the statement that the Greeks deliberately took up a position where they could make the most of the natural features in order to avoid the dangers of hostile cavally'y ${ }^{1}$ ); it implies not only that Miltiades was a thoroughly capable tactician, but also that the Persian cavalry, at least at the commencement of the fight, was a force to be reckoned with.

The actual topography of the plain of Narathon at the present day fully bears out these arguments and verifies the account of Nepos ${ }^{2}$ ). The valley of Avlona is bounded on the south by Mt. Agrieliki and Mt. Aphorismos, and on the north by Mt. Kotroni. All these three mountains are wooded and the two mountains on the south side are covered with what is, for all practical purposes, a forest which reaches right down to the level plain. The actual plain is for the most part cultivated, and so denuded of trees, but in the few places where it is not cultivated there are several large trees, and it seems quite possible that in ancient times the whole of the western end of the valley was well woodecl. It seems certain too that there were trees at fairly frequent intervals still further down the valley and well on to the main part of the plain, for the whole of the southern part of the plains along the coast towards the site of the ancient Probalinthus is covered with trees right down to the shore. The only part of the plain that was undoubtedly not wooded in ancient times is the part in the immediate neighbourhood of the Soros, between the Great and the Little Marshes.

Now Herodotus, after asserting that Marathon was $\dot{z} \pi \iota \tau \eta \delta \varepsilon\llcorner o \tau(c \tau o \nu$,

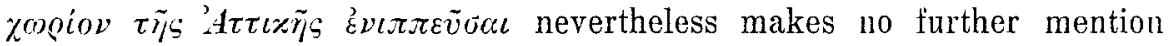
of the Persian cavalry at all: it has consequently been assumed that it never even landed from the Persian transports but was conveyed round to Phalerum as soon as the shield signal was given from Athens. But

1) Arborum tractu means that they scattered tree trunks and branches over the open spaces: they would hardly be likely to do this unless there were trees available on the spot.

2) I am indebted to Professor Lehmann-Haupt for the suggestion that the topography of Marathon supports the accout of Nepos, and I have since been able to verity it in detail myself. 
this statement of Nepos shows that the cavalry must at least have been landed, or the Greeks would hardly have taken such elaborate precautions. The statement that the country was dotted with trees seems directly

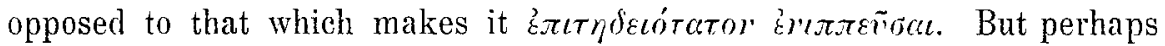
a way out of the whole difficulty may be found by assuming from the evidence of the nature of the actual site that the plain of Marathon near the sea was admirably suited for cavalry action, and that the Greeks, seeing this, remained in their safe position (which commanded the coast road to Athens and so was adequate to provent Persian advance) until the Persians re-embarked their cavalry and sent it round to Phalerum. Then it was that they descended $\delta$ orim upon the Persians.

Now the unsupported evidence of Cornelius Nepos for this completely different view of the outlines of the battle of Marathon is nut likely to be accepted without some hesitation. But when in addition to the support of topographical evidence the narrative of Herodotus implicitly, and perhaps unconsciously, agrees with it, its truth is rendered much more likely, however little value we attach to the version of Herodotus. Such implicit ayreement is found in the text: for Herodotus says

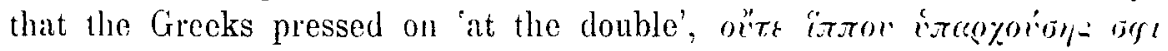
o't $\tau$ t $\tau$ (s) Greck force of cavalry, and it seems redundant to remark on the absence of it; but considering that Nepos had declared that the nature of the land was unsuited to cavalry and that the Greeks had taken advantage of this fact, the remark of Herodotus acquires a new significance. By itself it seems superfluous to say that the Greeks had not got either horsemen or archers: there were innumerable things that they had not got as well. But Herodotus has got such an inveterate habit of inserting incidental and omitting essential points that it may well seem that he stated a fact and forgot to mention the reasons for it: the fact being the absence of cavalry and archers, the reason, as Nepos says, being the incapacity to use them-which would apply a fortiori to the Greeks if they assumed it in regard to the enemy.

Undoubtedly the Persian cavalry was reembarked not so much for its supposed utility on the plains of Phalerum but because of the discovery of the deceptive nature of the place which had been specially selected for its mancuvres. There is no necessity to represent the plans of the

1) It seems hard to understand the absence of archers, considering the discoveries of large numbers of Greek lronze arrowheals on the fiell. See Hanvettr in Nouvelles Archives tes Missions scionlifiques vol. IT p. 326-335. They might possibly have belonged to the Greeks of Karystus, who were pressed into the Perwian service (ch. 99). 
Persians as over-elaborate: they might well have been mistaken in some of their assumptions.

The fact that the cavalry ultimately reembarked seems proved by the agreement of Herodotus and Nepos upon the point that the battle ended by the Persians being pursued to their ships: they were routed

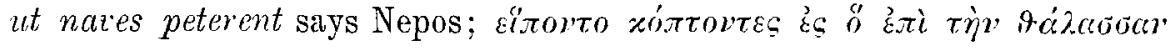

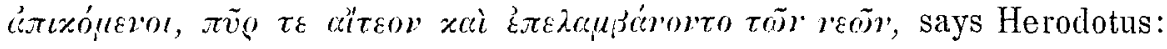
and they could hardly have done this if the Persian cavalry had been on the foreshore so eminently suited to their tactics.

The problem of the cavalry at Marathon is not solved by assuming that they were never intended to be landed at all, but were destined for Phalerum and were to start as soon as the Athenian forces were lured out of their city: there still remains this very definite assertion of Ilerodotus that they were especially brought to Marathon because it was so suited to their tactics. Herodotus, it is true, makes no further mention of them. But Nepos definitely assumes their presence. Suidas ${ }^{1}$ ) gives the story that the Ionians in the Persian fleet made a signal to the Athenians to the effect that "the horses are gone". According to Pausanias the field of Marathon in his time was said to be haunted by the noise of combatants and the snorting of horses: so that there is considerable anthority for the presence of cavalry at some time during the battle. They were undoubtedly absent at the end and at the height of the battle as well, but there seems every probability that they were landed just before the battle but re-embarked as soon as they realised the unsuitability of the place. It was this re-embarkation that was signalled by the Ionians, and it was not necessarily due in the first instance to any prearranged plan to convey them to Phalerum: they may ultimately have gone there, but they were intended for use at Marathon. In appears, therefore, that the cavalry upon which the Persians had decided to place most reliance turned out to be useless either for defence or offence. The plain was no

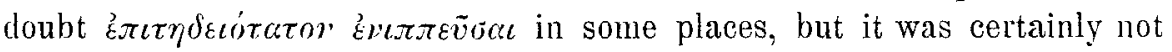
so in the particular place where the Persians found they would have to fight if they were to pass the Athenians and get to Athens. In fact, they had made a grave -strategical error, despite the advice which Hippias, from his experience of the locality, might have been supposed to give them.

In their account of the Parian expedition, however, Herodotus and Cornelius Nepos show most clearly both the nature of the sources they drew from and their respective prepossessions and prejudices.

Both historians agree that the expedition consisted of seventy ships and that it set out from Athens. After this, however, the two versions

1) See Macan's edition of Herodotus II p. 231. 
diverge and differ in so marked a way that it seems incredible that they both claim to represent the same facts.

The reason given for this expedition according to Herodotus was a definite promise on the part of Miltiades that he could put Athens in the way of a 'good thing' from the financial point of view-ràs a'tois

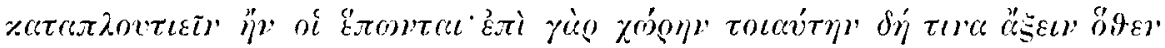

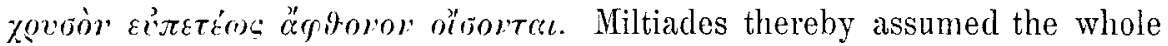
responsibility for the undertaking: it was, in short, his idea and due to his initiative, or rather his arrogance as Herodotus makes it out to be. In other words, Miltiades and the Parian expedition are delineated in Herodotus exactly as Alcibiades and the Sicilian expedition are in Thucydides. There is the same overweening self-confidence on the part of the leader, the same failure of the expedition, and a showing up of the leader in his true light. In short, all the best traditions of the Greek historical formula

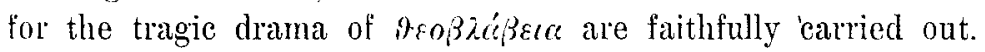

But Nepos, with his usual mattel-of-fact tabulation of events, brings us down from the clouds of tragi-history and gives a much more convineing and likely representation of the expedition.

Whereas Herodotus states that Miltiades on his own initiative asked

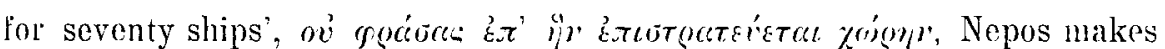
it quite clear that Miltiades was a servant rather than a master. Post hoc proplinem (Marathon), he says, classem septuaginta novium Athenienses eidem Miltiali dederunt, ut insulas, quac barbaros adiuverant, bello persegueretur, and later on reference is made to this mission as an imperium.

Now the account not only differs from, but in a sense contradicts, the account of Herodotus, and at the same time scems to be a far more plausible and probable version. The battle of Marathon was a great victory, no loubt, but no intelligent city would be likely to leave it at that: a further movement to consolidate its effects and to take more elaborate preeautions against a similar crisis seems to have been inevitable. The Parian expedition, as Messrs. Mitchell and Caspari') suggest, may have had as its object the establishment of an outer line of defence: Naxos was still unsubdued by Persia and 'the acquisition of the neighbouring and next greatest island of Paros would then have provided the Athenians with an excellent nucleus for an advanced line of resistance among the Cyclades'. Miltiades, further, was just the man for such an undertaking, for he had achieved success in the previous expedition to Lemnos. which cannot be looked on as anything else than a political move of the greatest importance. That the Parian expedition had a precisely similar motive is at least the inference from the account of Nepos. Instead of a wild

1) p. 159, note 2 . 
goose chase for an unexplained reason we have a definite policy of defence: Viltiades is given a commission-an imperium exactly the same as that of Pompey or Antonius in later days-ut insulas quae barbarns adiuverant bello persequeretur. Perhaps this is too much in the spirit of Athens during the critical time of the secession of members from the Delian league, but there is no other reason against it. Herodotus at any rate agrees on one point with Nepos, for he declares that Miltiades went to Paros (no

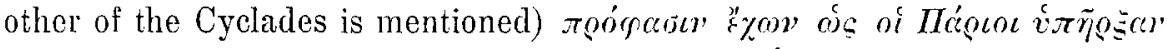

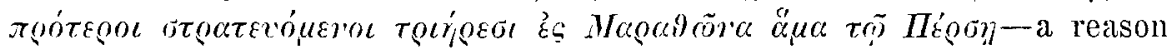
which might well represent a policy instead of a personal spite. But Herodotus hastens to dispel any such idea concerning his narrative by

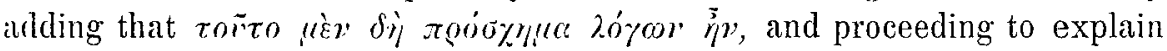
how it was all due to a private grudge that Miltiades held for the Parians because a certain Lysagoras son of Teisias had spread scandal about him to Hydarnes the Persian - a truly reasonable excuse for such an enterprise!

The expedition, however, seems to have been partially successful. Pleras ad officium redire coegit, nonnullas vi expugnavit, says Nepos: that is to say the formation of a ring of defensive bases was not only the intention but also the result of the expedition.

Herodotus represents him as going immediately to Paros. Nepos more reasonably includes Paros among other visitations: ex his Parm insulam opibus elatam, 'um oratione reconciliare nom posset, copias e navibus eduxit, and not only entirely ignores the 'private grudge' story, but says that Paros was opihus elatam and arrogant-the usual prelude to subjugation.

The siege then began, and, says Herodotus, a messenger was sent by Miltiades to the Parians, demanding a hundred talents. Nepos makes no mention of this demand, but it obviously falls into line with his statement that the island was opibus elata, though Herodotus uses it rather to depreciate Miltiades and show him in the light of a bandit.

The siege, however, was not destined to be a success, and it was abruptly bronght to a close. The two rival versions, however, differ in such an extraordinary way on this point that we are driven to the deepest scepticism in regard to our knowledge of Greek history which depends on such variable sources.

Herodotus relates that Miltiades owing to the failure of the siege and his despair of ever taking the city, commenced negotiations for its betrayal with the priestess Timo. Then follows the well-known story of

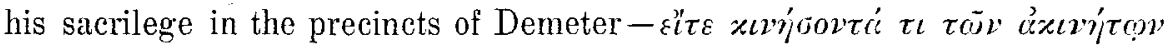

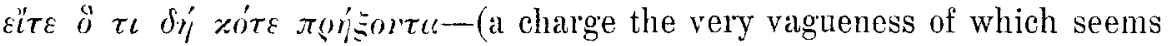
to make it seem more serious), and then his accident and abandonment of the siege. 
Now Nepos gives the following account of the crisis in the siege. So far from the siege being a failure, he says that Miltiades was 'just on the point of taking Paros': but that one night a forest on the island suddenly for some unknown reason caught fire: both the besiegers and the besieged instantly jumped to the conclusion that it was the Persians come to the help of the Parians, and that the fire was the Persian signal to the besieged. Miltiades therefore burnt his engines of siege and fled in a panic.

Now the sensational element in each narrative seems to be unduly emphasised and each differs so entirely from the other that there is no question of their being rival interpretations of the same story. They have no single element in common, except, perhaps, the suddenness of the abandonment of the siege.

But though it seems hard to adhere to either version, yet Cornelius Nepos seems in some respects to give the more reliable story. Thus Herodotus, while he states that the siege was a failure, yet gives no reason for its sudden abandonment. His story of the negotiations with Timo is a mere interpolation: it neither explains the alleged failure, nor yet the sudden abandonment: it is, in short, but a scandalous story about a man whom Herodotus had been briefed to depreciate.

Nepos, however extravagant he may seem, yet gives a perfectly logical account. The siege was going on perfectly successfully-cum iam in eo esset ut oppido potiretur-but a sudden catastrophe sent Miltiades flying headlong back to Athens: the flight, moreover, was caused through a fear of precisely those enemies whom Miltiades was sent to oppose, and so perhaps the sensational nature of the story can be minimised, considering the immense number of parallel instances of panics at night time both in ancient and modern warfare. In any case it is coherent and consistent, while the version of Herodotus is neither the one nor the other, for it leaves much that is unexplained and postulates much that is unnecessary.

As one might expect, on his sudden return to Athens, whence he had set forth with such an important commission, Miltiades arrived magna cum offensione civium suorum. He had not only not redeemed his

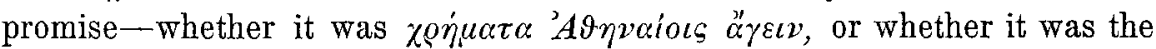
formation of the Second Line of defence-but in addition he had wasted time and money in a worthless and fruitless venture of twenty-six days' duration.

At this point Herodotus attempts to remould his version by continuing the story of Timo, the priestess. The Parians, he says, sent $\vartheta \varepsilon \dot{\pi}$ оолол to Delphi to ask for advice as to her conduct. The oracle replied that it was no fault of the priestess, but the working of the fate of Miltiades. However this may be, it has little bearing on the outlines of the story.

Kl10, Beltrage zur alten Geschıcht XIV $_{1}$. 
Miltiades returned in disgrace: that is admitted by both authorities. Further, this disgrace took a severely practical form, and he was impeached. Here Herodotus is very definite: the Athenians, he says, were talking

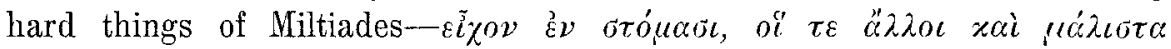

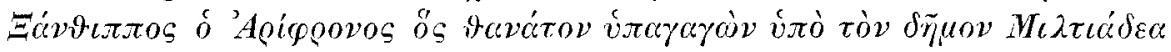

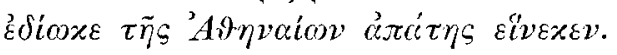

The two rival narratives now seem to come together again. Nepos likewise says that the magna offensio caused by Miltiades' ignominious return led to an accusation-accusatus ergo est proditionis, quod, cum Parum expugnare posset, a rege corruptus infectis rebus discessit. But he differs from Herodotus in three points. First, Herodotus says the

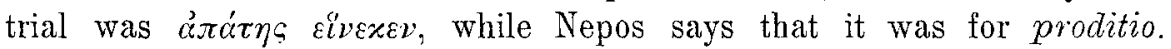
Secondly, Nepos adds a further charge of corruption. Thirdly, the incidental references to the Persian King and to Miltiades' abandonment of an otherwise successful siege are both consistent with the reason for and the progress of the expedition as previously narrated.

Now $\alpha \pi \alpha^{\prime} \tau \eta$ is just the vague sort of reason that Herodotus usually gives for political trials such as this. Proditio-no doubt a species of $\dot{\alpha} \pi \dot{\alpha} \tau \eta$-is, on the other hand, much more likely if the reason for the expedition was an anti-Persian plan of action.

Miltiades, however, fell ill-from the wound received on the occasion of his sacrilege, according to Herodotus: according to Nepos, from wounds received during the siege-eo tempore aeger erat vulneribus, quae in oppugnando oppido ceperat. He was unable therefore to conduct his own case and left it to his sizol-(Nepos says to Stesagoras or to a certain Dagoras, according to the reading: but Stesagoras had been assassinated years before, so it may have been another member of the family of that name).

He was accused chiefly by Xanthippus the son of Ariphron, says Herodotus, who demanded a death sentence. Nepos is silent on this point. In any case, however, the part played by the Alemaeonidae in this trial may well have been played in the previous trial of 493 , and both are palpably political coups: the power of the Alcmaeonidae had been considerably lessened by the growing popularity of the Philaidae, and this was an admirable opportunity for recovering their lost prestige.

Miltiades was condemned, but not on the capital charge, and he

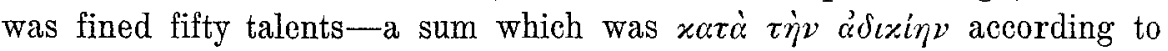
Herodotus-or quantus in classem sumptus factus erat according to the more exact statement of Nepos.

He was, however, unable to pay the fine and in vincla publica coniectus est. Herodotus makes no mention of this latter fact, but it is given by Diodorus ${ }^{1}$ ) and Plutarch ${ }^{2}$ ). In prison, however, diem obiit

1) frag. lib. X. - 2) Kimon 4 and Aristides 26. 


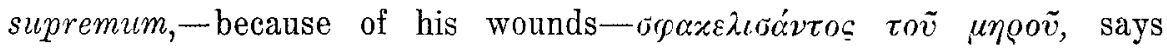
Herodotus.

No criticism of the trial at all appears in Herodotus: but Nepos particularly distinguishes between the nominal charge and the real underlying motive of the trial.

The latter, the alia causa damnationis was the Athenian fear of tyranny after their experience of Peisistratus-nimiam ${ }^{1}$ ) civium suorum potentiam extimescebant. Now this is identical with the reason given by

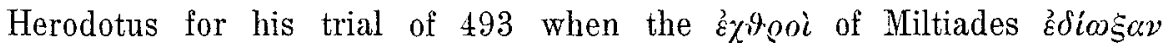
cvoóvvidos. There is no reason, it is true, why the same cause should not have acted in each case, but the two trials are not free from suspicion of being confused by one or both of our authors.

Now the comparison of the two versions of the events during the period of early Persian aggression has raised many problems for historians: We are faced first of all with the great problem of the sources of the history of the times of the Persian aggression. What evidence was available to contemporary historians, and how did they make use of it? and what accounts for the difference in so many essential points between the accounts of Nepos and Herodotus?

Even a cursory examination of the Herodotean narrative of the period shows that he used Alcaemonid sources for the greater part of the incidents he describes and particularly for the battle of Marathon. Whatever the other sources were that he used it is fairly certain that they were neither those of the house of the Peisistratidae nor those of the Philaidae. In particular his apologia for the action of the Alcmaeonidae at Marathon seems too obviously inspired to be spontaneous.

The whole narrative of Nepos, however, always omits just those points which can be conclusively held to be due to such inspiration. And not only is there this absence of Alcmaeonid traditions but there are definite and positive traces of some other traditions. What these traditions are remains to be seen. Lastly there is without doubt a certain amount of influence from subsequent history reflected in his narrative: the later fifth century and its ideals seem to be mainly represented. But a scrutiny of the evidence alone can throw light on these somewhat intangible points.

The chief points in the narrative of Herodotus which seem to be derived from Alcmaeonid traditions are the following:-

In his account of the battle of Marathon the incident of the raising of the shield is mentioned as a charge laid at the doors of the Alcmaeonidae only to be hastily condemned: but the impression that it leaves

1) Or omnium. 
is markedly one of 'qui s'excuse, s'accuse'. The reference to Harmodius and Aristogeiton in the speech of Miltiades at least rules out any Peisistratid traditions.

In the account of the Parian expedition we find first of all the explanation of the áxát $\eta$ by which Miltiades coaxed Athens to lend him an armed force to use for his own private purposes. Then there is the definite assertion that the reason given by Miltiades for his attack on

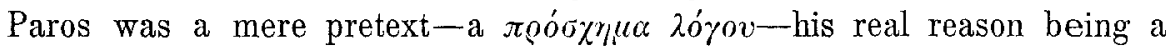
personal quarrel with the Parian Lysagoras.

The demand for money and the negotiations with Timo, above all, are due to traditions of a very anti-Philaid nature: and the attribution of the wound which caused his death to the occasion of the sacrilege seems an almost unnecessary piece of spite.

The definite statement that Xanthippus undertook the conduct of the impeachment coming on top of all this evidence seems to point to the common Alcmaeonid origin of all the stories-thongh, as has been suggested ${ }^{1}$ ), the story of Paros may be derived actually from Paros itself.

Now not one of these 'Alemaeonid' incidents is mentioned by Nepos, and nevertheless he gives a more coherent and convincing account without showing traces of any suppression or omission in the narrative. But he goes further and tells many things about Miltiades which not only redound to his credit but throw an entirely different light on the course of events. These can be summarised as follows.

The Lemnian Expedition was the occasion for the first demonstration of what might be called the 'Cycladic policy', and Miltiades, like his son in later days, seems to have had a commission to strengthen the defences of the islands against the Persians.

At Marathon the whole plan of the battle according to Nepos shows Miltiades in the light of a capable general and the battle as a tactical victory rather than a forlorn hope. The timing of the discussion of the generals and the arrival of the Plataeans before the departure from Athens, the nature of the site chosen for the camp, and the tactical use made of the natural features-particularly the trees and mountains-all point in the same direction.

But the account of the Parian expedition is a still gxeater vindication of Miltiades. Not only are none of the 'Alcmaeonid' points mentioned, but we learn that in this case too Miltiades showed throughout an eminently laudable statesmanship. He set out with a commission-an imperium-to clear the seas of Persian influences: this he did by subduing many islands, amongst which was Paros: and he was within

1) Mitchell \& Caspari's Grote, p. 159, note 3. 
an ace of subduing Paros when an accident caused in his ranks a panic such as has overtaken many of the most experienced generals. He was

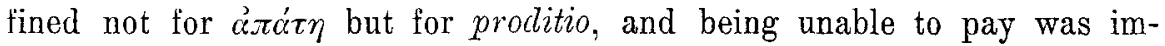
prisoned and died in prison of wounds honourably gained: whereas in Herodotus the scandal of Timo pursues him right to his grave.

Now Cornelius Nepos is supported in many of these points by the historian Ephorus. Thus the assertion that Miltiades was imprisoned is repeated by Diodorus and Plutarch, who both drew largely from Ephorus. The account of the sudden abandonment of the siege of Paros and the forest fire which was mistaken for a Persian onslaught is given verbatim in Ephorus ${ }^{1}$ ), though it is located by him at Myconos, while Nepos says it was on Paros itself and does not mention that the Greeks thought that it was caused by the forces of Datis, as Ephorus does.

It seems, therefore, highly probable that Nepos derived much from Ephorus. But this solution only pushes the problem further back, and we have still to ask whether Ephorus derived his information from Alcmaeonid, from Peisistratid or from Philaid traditions. This, unfortunately, is a problem which we cannot easily solve with so scant a knowiedge of Ephorus at our command.

But in regard to Nepos, we can definitely rule out the Alcmaeonid sources and trace most of his narrative unreservedly to his knowledge of the traditions of the Philaid house. His favourable and apparently accurate account of the events in the life of Miltiades is sufficient evidence by itself to prove this-quite apart from the 'authentic' character of nearly all his narrative.

An independent pice of evidence for the existence in the time of Cornelius Nepos of sources for this period of Greek history which were not solely Alcmaeonid in character is seen in the isolated fact given by Cicero ${ }^{2}$ ), that Hippias died at Marathon. Herodotus does not mention it, curiously enough, although his Alcmaeonid informants would have no particular desire to screen the Peisistratidae. It is not given by Nepos, and the only other author to mention it is Justin ${ }^{3}$ ), who probably derived it from Cicero. Perhaps Cicero derived it from Ephorus: but the only inference we are really justified in drawing is that in the time of Cornelius Nepos there were available certain sources for Greek History that were tinged neither by Alcmaeonid nor Peisistratid preferences $\left.{ }^{4}\right)$. Whether they were Philaid sources it seems impossible to say, but there seems every probability that it was from such that Cornelius Nepos drew to a very

1) $F H G$ n. 107. - 2) Ep. ad Att. IX, 10. - 3) II, 9.

4) If the reading Dionysii is adopted in place of Dinonis in another passage (see Gaisford: Suidas, p. 1018, note M), Cicero appears to have known the works of Dionysius of Miletus. 
large extent. It is not therefore unreasonable to attribute to them this isolated fact about Hippias as well.

But to identify such sources firstly with Ephorus and then with Philaid traditions is merely to make them a little less vague. To solve the difficulty it is necessary to search for a still more definite source, for Philaid traditions must have been collected in a form in which they were easy for historians like Ephorus or Nepos to draw upon.

Now since the sources used by Herodotus are for the most part Alcmaeonid, they are a priori therefore of a pro-Athenian and anti-Ionian nature: and this is borne out by facts, for it is notoriously the aim of Herodotus to shew Athens as the Saviour of Greece, and to achieve this end he suppresses all suggestion of Medism at Athens or ill-treatment of Ionians. The pủnishment of Phrynichus for his Ionic patriotism is but one of the many anti-Ionic actions of the Alcmaeonids which escaped his censorship, and we can be sure that there were many more which did not escape.

If therefore the account of Nepos brings out precisely those points which Herodotus either passed over in haste or else suppressed altogether, it stands to reason that the sources of that account must be both Ionian and anti-Alcmaeonid, and, in a sense, anti-Athenian.

Now the historian who dealt with the history of the Persian Wars in precisely this spirit was Dionysius of Miletus. He wrote his $\Pi \varepsilon \rho \sigma \iota x \dot{a}$ $\left(I \dot{\alpha} \delta \delta_{\iota} \delta(\alpha \lambda \dot{\varepsilon} x \tau(m))^{1}\right)$ purely from the Ionian point of view. "This Ionian Logos of the Persian War was, we may conjecture, a challenge to unreserved admirers of Athens", says Prof. Bury ${ }^{2}$ ). As such, it would naturally bring out in full detail such points as are brought out in the narrative of Nepos, and omitted in that of Herodotus.

Herodotus, as has already been pointed out ${ }^{3}$ ), undoubtedly drew to a considerable extent from Dionysius of Miletus, particularly in certain points, but only in the case of the facts of less importance and less open to dispute $\left.{ }^{4}\right)$. This is, of course, additional evidence to prove that an Ionian history of the Persian Wars was both available and well-known.

Now just as Herodotus drew on Alcmaeonid sources for his history, so we can conjecture did Dionysius of Miletus draw upon Philaid sources. Herodotus, in all probability, wrote his history at Athens, where, presumably, oral Alcmaeonid information and memoirs would be available. If it is seen that Philaid traditions and memoirs were available at Miletus then the probability that Dionysius drew upon them is considerably strengthened.

1) Suidas, v. under Dionysius. - 2) Greek Historians, p. 22.

3) Lehmann-Haupt in Klio, 1902, p. 334 et seq.

4) As for instance in the case of the advice of Hecataeus, the names of Cyprian potentates, etc. Prof. Lehmann-Haupt deals most thoroughly with all these points. 
That this was so is for all practical purposes a mere conjecture, but it is strengthened by the facts that the Philaid stronghold of the Chersonese is within easy reach of Miletus either by sea or by way of Sigeium, and that Lemnos was equally accessible. Mr. Grundy ${ }^{1}$ ) asserts of Herodotus that his lack of information about Miltiades from the time of the Scythian expedition to that of the Ionian revolt was due to his lack of documentary evidence. "Had the historian made large use of private memoirs," he says, "supposing such existed, it is unlikely that he would have omitted to have recourse to the records of the Philaid family". But the assumption that if he had access to memoirs of one family he would ipso facto have had access to those of another is directly contrary to Greek historical method, and is in no way justified: moreover, it is a certainty that Herodotus had free use of Alcmaeonid memoirs and that would of itself prevent him from making much use of Philaid memoirs if his history was to be in any way coherent.

Dionysius of Miletus, however, had little or no chance of using Alcmaeonid memoirs, and he certainly had no reason to do so if his history was to be written in the Ionian spirit as well as in the "Ionian dialect": whereas he had ample opportunity and full justification for using memoirs and traditions of the Philaidae, which, we may not without reason assume, were to be obtained through the medium of men like Aristagoras who were personally acquainted with Miltiades the younger. Moreover, it is safe to assume that Miltiades was not only well-known but also popular at Miletus, for it is he whom Herodotus sets up as the protagonist in the dispute with Histiaeus, the tyrant of Miletus, and being represented as the would-be liberator of the Milesians, it is hard to imagine that he and his history would be ignored by a writer of Ionian history. There is, therefore, not only a very strong a priori case for the use by Dionysius of Philaid traditions and memoirs, but also considerable evidence to show that he actually did so: and since the source of the account given by Nepos of the Persian Wars seems to echo Philaid traditions more than any others it is difficult to avoid the conclusion that he drew largely from

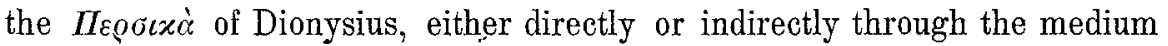
of some writer such as Ephorus. That he used a Greek historian is certain, judging by the large number of Graecisms in his vocabulary ${ }^{2}$ ).

There is one point, however, in which the narrative of Cornelius Nepos may well be questioned. As was mentioned above, his account of the Lemnian and Parian expeditions presupposes a very extensive policy of combined offence and defence against the Persians. In each case Miltiades was commissioned by the Athenian people to strengthen Athenian

1) The Great Persian War p. 146, note.

2) Cf. Macan: Appendix I, paragr. 14. 
power in the Cyclades. Now, as Messrs. Mitchell and Caspari suggest, all this seems to be too much in the vein of the later fifth century and too reminiscent firstly of the purpose and formation of the Delian league and secondly of the suppression of its revolted members: for a city or island to be opibus elata, as Nepos says of Paros, was always the prelude to its revolt from Athens. The forest fire on Paros which Ephorus and Nepos alike describe, and which was the immediate cause of the retreat of Miltiades, reminds one rather forcibly of the similar fire on the island of Sphakteria in 425 , So that Nepos is not quite free from the suspicion of interpreting earlier history by later, just as the fourth century orators described Solonian Athens in terms of the Athens of their own age.

But it is much more likely that the resemblances are mere coincidence, and Nepos may, after all, be giving the most valuable historical evidence. And this suggests that a revision of the traditional account of the history of this period is necessary. A 'Cycladic policy' as early as the time of the Lemnian expedition is a fact which might well have been one of the preliminaries to the Ionian revolt, and it might equally well have been a further reason for the expeditions of Mardonius and of Datis and Artaphernes. Probability is still more in favour of a renewal of the policy after Marathon as the Greeks were never that happy-go-lucky nation that Herodotus would make them out to be: there was a least a method in their madness.

An establishment of a strong base on Lemnos would be the least that Athens could do either before or after the Ionian revolt. At any rate somewhere about the time $513-510$ B. C. Miltiades was engaged in establishing Athenian power in the North East Aegean. Peisistratus before him had already paved the way by establishing friendly relations with the people of the district round Pangaeum ${ }^{1}$ ), which, though primarily for his own advantage, would nevertheless be to the advantage of Athens when he was restored, and an Athenian outpost had been established at a still earlier date at Sigeium, and was itself in friendly communication with Proconnesus ${ }^{2}$ ). Lemnos would be of the utmost strategic importance if any check was to be put upon Persian ambition, for it lay within reach of the two outposts of Sigeium and Pangaeum, and could thus establish communication between the two. The Thracian Chersonese would probably have been a still better base, and undoubtedly Miltiades' mission thither served the double purpose of exiling him and strengthening the outer line of Athenian defence: but it was too difficult a place for him to hold and he had to fall back on Lemnos. The coincidence in time, however, of the two visits of Miltiades to Lemnos and the Scythian

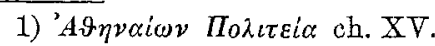

2) Cf. the famous Sigeium inscription: Hicks and Hill, Greek Inscriptions, no. 8. 
expedition of Darius is, perhaps, the strongest reason for attributing to those visits a political purpose and identifying them with the first active results of Athenian 'Cycladic Policy'. Athens not only feared Persia, but was stirred by that fear to take precautions of a very practical nature against the growing menace. The rapidity of subsequent events and their great importance and interest tend to obscure the fact that Athens was not only strong enough but was also wise enough to act in a very definite and effective way. The attempt of the Phoenician squadron of the Persian fleet to capture Miltiades is ample proof that Persia realised the schemes of Athens.

The detailed account of the strategy of Marathon is a fact which points in the same direction-namely, towards a representation of the Greeks as deliberately arranging a plan of action for the battle, just as they deliberately originated a general poliey. All the battles in the Persian Wars are, if we believe Herodotus, brilliant examples of heroism and poor ones of strategy. But it is difficult even in the case of his description of a battle such as Plataea to deny the Greeks any capacity for strategy. The account of Marathon, therefore, given by Nepos seems to act as a corrective to Herodotus. At any rate, neither can claim to be derived from superior sources, and if Herodotus has the weight of tradition behind him the narrative of Nepos at least derives considerable force from its plausibility. It is, further, of no little importance that the account of the battle given by Nepos agrees in detail with the nature of the locality. From Nepos we gather that the Greek camp was on a level wooded place at the foot of the mountains which surround the valley of Avlona. Herodotus, it is true, says that the Greeks were $\varepsilon^{\prime} \nu \tau \varepsilon \mu \varepsilon \dot{v} v \varepsilon \ddot{i}$

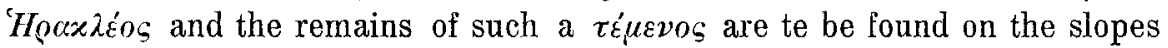
of Mt. Kotroni. But Herodotus may only have meant near the $\tau \dot{\varepsilon} \mu \varepsilon \nu 0 \varsigma$ as it is in any case not large enough for 10,000 men. The most likely site for the camp seems to be on a level platform at the foot of the $\tau \varepsilon_{1}^{\prime} \mu \varepsilon v \circ s$ and on the opposite slopes of Aphorismos where there is now a small shepherds' hamlet, and there is every likelihood that this level platform was originally defended on all sides by trees such as now appear in the neighbourhood on the plain and on the slopes of Agrioliki and Aphorismos. It seems hardly likely that the camp was on the spur to the north of the modern village of Vrana, for it is altogether too small and to.o steep either to accommodate such a large body of men or to agree with the description given by Nepos.

Unfortunately, a middle course between the two accounts cannot be arrived at, for, so far from being mutually supplementary, they are directly at variance on so many points. The site of the camp, for instance, the attack of the Greeks and the problem of the cavalry are all 
instances in which the accounts cannot be reconciled. But on the whole Nepos seems to give the preferable version both of the two Cycladic expeditions and of Marathon, although in many points he too is untrustworthy.

The comparison, therefore, of all the evidence of Nepos with that of Herodotus for the accounts of the Lemnian Expedition, the battle of Marathon and the Parian expedition show that throughout Herodotus is tempted by his prejudices and prepossessions to distort the history he relates. Alcmaeonid traditions and memoirs had got too strong a hold of his imagination to permit him to give an impartial account. Philaid traditions, which would obviously be the best to use for these particular events, he seems to have been either unable or unwilling to use. Dionysius of Miletus, on the other hand, seems to have had free access at Miletus to the memoirs of the family of Miltiades, and it seems to have been from his works that Nepos drew when writing his Vita Miltiadis. However partial to Miltiades such a history may have been, it must still have been more true to facts than the very partial and biassed accounts which the Alcmaeonidae would have given to Herodotus. The generalship and genius of Miltiades which his prominence in Greek history implies and the early elaboration of a Cycladic policy which the subsequent course of history seems to justify, are factors of the very highest importance in Greek history, of which, if we relied solely upon Herodotus, we should remain in complete ignorance.

Athens. 